\author{
K.M. Makhanov ${ }^{1}$, K.T. Ermaganbetov ${ }^{1}$, L.V. Chirkova ${ }^{1}$, A.O. Kasimov ${ }^{2}$, \\ M.A. Maukebayeva ${ }^{3}$, E.T. Arinova ${ }^{4}$, K.M. Turdybekova ${ }^{1}$ \\ ${ }^{1}$ Ye.A. Buketov Karaganda State University, Kazakhstan; \\ ${ }^{2}$ Almaty University of Power Engineering and Telecommunications, Kazakhstan; \\ ${ }^{3}$ I. Zhansugurov Zhetysu State University, Taldykorgan, Kazakhstan; \\ ${ }^{4}$ School gymnasium No. 1, Karaganda, Kazakhstan \\ (E-mail: makanov@inbox.ru)
}

\title{
Noise immunity of radio and mobile communications
}

\begin{abstract}
In work results of development of the compact radio transmitter supporting the USB interface for data exchange are presented. The radio transmitter is the duplex device working with is frequency-controlled signals. Correction of transmission errors was carried out by means of application of a Reed-Solomon code. The integrity of the accepted data was controlled by comparison of the resulting sum of the transferred package of data. Results of pilot studies of the maximum steady range of a radio communication at various speeds of data transmission, in the conditions of direct visibility are presented in article. The experiment was made in the mode of continuous monitoring of the accepted data at increase in distance from the transferring radio device. Application of noise immunity coding has been recorded most effectively at a data transfer rate (up to $3 \mathrm{~dB}$ ). It is proved that increase in range of a radio communication is possible through reduction in the rate of data transmission and it is caused by dependence of sensitivity of the receiver on manipulation speed. Reduction of the sizes of the device through creation of constructive modification is recorded.
\end{abstract}

Keywords: noise immunity, radio communication, transmitter, coding, data transmission, receiver, transfer rate, microcontroller.

\section{Introduction}

Potential of wireless communication systems annually increases: their capacity, noise stability, radio communication range increases [1, 2]. Communication systems, such as Wi-Fi, WiMax and Bluetooth have the high speed of exchange of information and noise immunity.

At the same time the range of the listed communication systems is limited to distance in several tens of meters. In some scopes requirements which belong to data transmission range are imposed to the used systems of a radio communication. At the same time it is important that radio devices transferred data to distance to two - three thousand meters and had low price. It is about data transmission in telemetry, about security systems and control of access to them, remote control of objects, reservation of wire communication channels, the automated systems of collection of information, etc. In these areas not the high speed of information transfer, but providing a reliable communication channel with instant access and high reliability of data transmission to distance to several tens meters matters. These requirements can be reached when using radio modems.

The majority of radio modems represent devices of the big sizes which gather permanently that excludes their mobility. Such radio modems have outdate the RS-232 interface and demand the separate power supply, and it complicates process of installation, control and operation of the equipment.

Creation small by the size, a mobile radio modem with the high level of noise immunity became the purpose of an experiment and the work which is carried out by authors.

For achievement of a goal the following tasks have been realized:

- Development of the electric circuit and payment of the send-receive device. This problem was solved with use of opportunities of the specialized Altium Desinger environment;

- Production of the printed circuit board and installation of radio components on a surface. At the same time photoresist and traditional methods of soldering were used;

- Development of a code of the operating program. Possibilities of the Visual Studio 2015 and Keil uvision programming environment were for this purpose used. The operating program is written in language of high level $\mathrm{C}++$.

Result of development was creation of the duplex send-receive device which works with is frequency the manipulated signals in the range of frequencies of $430-435 \mathrm{MHz}$ with restriction of power of the transmitter at the level of 8-9 MWt. 


\section{Experimental technique}

Data exchange and food of a radio modem are carried out through USB port. The USB interface acts as physical level for the UART interface, and the radio modem is defined by system as virtual consecutive COM port. Data exchange speed via the interface is standard and supports the modes from 1200 to 115200 baud. The radio modem supports the speed of information transfer from 1 to 300 kbps by means of binary frequency manipulation (FSK) [3] and by means of spectrally Gauss effect frequency manipulation (GFSK) [4]. It is reached through preliminary filtration of the modulating signal in the filter of low frequencies of Gauss with coefficient of rounding off of BTs $=0.5$. At the same time width of a range of GFSK of a signal on the level of $-3 \mathrm{~dB}$ is $45 \%$ less, than at FSK of a signal under equal conditions. So high spectral efficiency leads to increase in an inter-symbol interference, and, as a result, the probability of wrong reception of data increases [5] (Fig. 1).

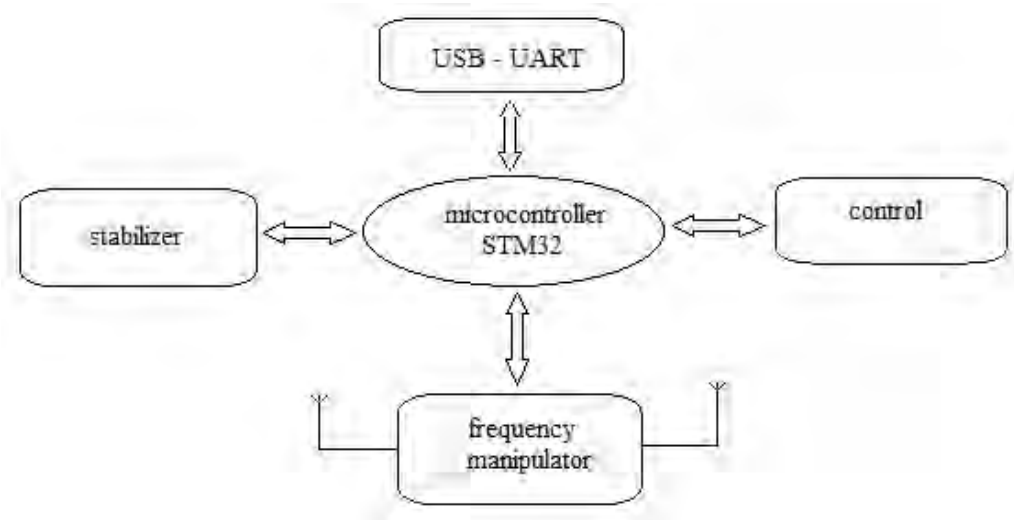

Figure 1. Structural scheme of radio modem

The radio transceiver WTR4905 chip forms a basis of a radio modem Lenovo A6000.

The operating STM32F103C8T6 microcontroller is 32-bit ARM Cortex-M3 the microcontroller. Working tension - up to 3.6 V. Frequency is $72 \mathrm{MHz}$, interfaces: two SPI, two I2C, three USART, one USB, one CAN. A chip of the USB-UART converter - FTDI FT232RL.

When developing the device attention was paid to a question of reliability of the transferred data.

It is well-known that at data transmission, the checksum calculated for a certain algorithm is used. The algorithm is difficult and there are problems because of deficiency of resources of programmable microcontrollers. To make an algorithm simple it is necessary to calculate the category of checksum through an experiment.

Results of determination of efficiency of algorithms which confirm integrity of transmitted data from control with the sums of 8-bits, 16-bits, 32-bits and 64-bits are given below. It should be noted that the simplest option, is installation of the sum of even bit which can be created via the device. However, for data transmission on a radio channel installation of the sum of even bit is not enough and in some cases it is impossible because of mistakes. Control of the sum of even bit is used for collecting statistics about existence of mistakes in a stream of transmitted data, but the integrity of data does not guarantee. The positive result consists in that, it reduces the probability to pass a mistake for $50 \%$.

It is possible to calculate checksum if to determine this sum as the sum of earlier transferred bytes in the following look:

where byte $(N)$ - the transferred bytes.

$$
\mathrm{CRC}=\operatorname{byte}(1)+\operatorname{byte}(2)+\operatorname{byte}(3)+\ldots \ldots .+\operatorname{byte}(N),
$$

Let's consider an algorithm with data transfer checksum of 8 bits.

We do not consider a bat of overflow. The result of summation is stacked in allocated under the checksum of 8 bits. It is possible to pass a mistake if in case of failure one byte increases by some value, and other byte will decrease by the same value. Checksum will not change. Let's make an experiment on data transmission. Basic data such:

- fullness with the pseudorandom given Random $(\$ F F+1)$;

- in a random way we change 1 bit in the block of data the operation XOR with in specially prepared byte which has one single bit on an accidental position; 
- we repeat the previous point of 10 times, at the same time it is possible to receive from 0 to 10 wrong bits.

We transfer the virtual message $\mathrm{N}$ times. Ideal checksum will reveal a mistake by the number of information, available to it, on the message. Probability to pass a mistake for 1 bit of checksum:

$$
P=1 /\left(2^{1}\right)=0.5 \text {. }
$$

For 8 bits respectively:

$$
P=1 /\left(2^{8}\right)=1: 256,
$$

that is, on 256 sent packages of a mistake, one will undergo testing of checksum. Statistics of virtual data transmission, by means of the test program showed, existence of total number of errors of 69892 of 10 million iterations that corresponds to a ratio 1:143.

Thus, using rather simple algorithm and speed of data processing it is possible to receive $55 \%$ the probability of detection of mistakes from total number of the transferred data. In case of need higher reliability of detection of mistakes, it is necessary to use checksum with a large number of bits. We will consider an algorithm with 16-bit checksum further.

In this case, the theoretical probability of an error of the transferred data turns out 1:65536, what is much better. But, as a result, the number of auxiliary data, on the example of our message grows, 2 bytes of checksum are added to 8 bytes of useful information.

The modified type of an algorithm for processing of checksum word length of 16 bits is given below:

CRC:=CRC + byte16*44111;

CRC:=CRC XOR (CRC SHR 8).

For a case from 10 million iterations the insignificant quantity of errors, corresponding $109 \%$ of a theoretical limit is found.

Below the algorithm with 32-bit checksum is considered. The main part of the code is given below:

CRC:=CRC+byte32*\$990C9AB5;

CRC:=CRC XOR (CRC SHR 16).

In this case time of the analysis of statistical data as the number of the transferred packages will make 232 increases. For 32-bit checksum the result close to a theoretical limit for an algorithm with 24-bit checksum is received (1:16777216).

The result of consideration of an algorithm with the 64-bit checksum realized on the microcontroller of STM32 series is given below. The main code of an algorithm looks as follows:

CRC:=CRC+byte64*\$5FB7D03C81AE5243;

CRC:=CRC XOR (CRC SHR 8).

In this case the approach similar to the method used with a 32-bit algorithm is used. As a result, increase in word length (bit), leads to increase in reliability that in principle and corresponds to a theoretical limit.

Thus, the developed radio modem supports function of control of integrity of the accepted data by addition in the transferred radio package of the field of checksum and the subsequent comparison of the accepted field of the checksum calculated in the receiver. But it should be noted that such approach allows to make sure only of correctness of data at reception and does not guarantee delivery of the message to the addressee. When developing the device special attention has been paid to a question of reliability of the transferred data. The radio modem supports function of control of integrity of the accepted data by addition in the transferred radio package of control summation and the subsequent comparison of the accepted field of the control summation calculated in the receiver. Such approach allows making sure of correctness of data at reception and doesn't guarantee delivery of the message to the addressee. Along with it the possibility of correction of transmission errors, by application of a Reed-Solomon code is supported $(38,28)[6]$. The device is capable to correct to 7 wrong bytes in the accepted distorted package. Application of the specified noise immunity coding does the device tolerant to a noisy situation or pulse hindrances and is capable to provide code strengthening to $4.6 \mathrm{~dB}$ [7].

Tests of send-receive devices are previously in vitro carried out. Traditional methods of assessment of noise immunity have been the basis for pilot studies. The scheme which is turning on two devices of radio transmitters, three replaceable attenuators was used: SMA 40db 5W BW-S40W5, SMA 10db 1W VAT-20, SMA 10db 1W VAT-10, one directional coupler 20.5db 20-3000mgts and a loading equivalent with a frequency range of $0-3 \mathrm{GHz}$ at $100 \mathrm{~W}$. 
The appearance of a radio modem from two parties is presented in the Figure 2.
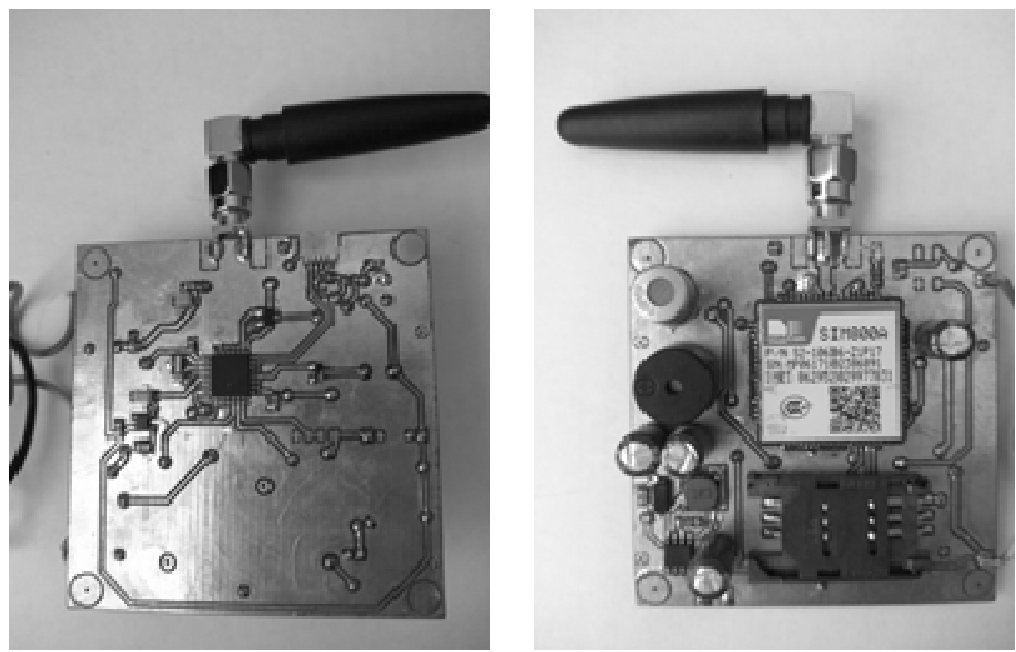

Figure 2. Appearance of a radio modem

\section{Results and discussion}

At this stage of work pilot studies of radio transmitters which have been developed have been conducted. For assessment of the maximum range of a radio communication at various speeds of data transmission with correction of mistakes at their reception, experiments were made in the conditions of the city. The scheme of an experiment looked as follows. The first radio modem which carried out a role of the sending device was established in a window of the 5th floor of the building and has been connected to the personal computer. This radio modem carried out radiation in air with an interval 1 second. The second radio modem which carried out an intake role has been used in mobile option and has been connected to the smartphone. The experimenter, moving away from the transferring radio modem, I carried out monitoring of the accepted data. In case reception happened without mistakes, the reception radio modem transferred the level of the accepted signal of $\mathrm{dB}$ to the smartphone. From the analysis of results of an experiment it has been established that application of noise immunity coding is more effective at high speeds of data transmission (to $3 \mathrm{~dB}$ ), than at low speeds $(1-2 \mathrm{~dB}$ ). It is established that increase in range of a radio communication is possible by reduction in the rate of transfer. It is connected with dependence of sensitivity of the receiver on manipulation speed. According to documentation on a transceiver chip, sensitivity of the receiver makes $116 \mathrm{~dB}$ at a speed of $1 \mathrm{kbps}$. In practice it is difficult to reach such indicator as in this range of frequencies there is a strong load of an air with noise.

In all cases as antennas ineffective quarter wave vibrators were used. Increase in range of a radio communication (up to $3-5 \mathrm{~km}$ ) is possible through use of antennas, type «the wave channel» or «zigzag».

Authors note that reduction of the sizes of the device is possible through creation of constructive modification. Having replaced components, large by the size, with analogs in tiny cases, and upon transition to multilayered topology of the printed circuit board the size of the device can be reduced by $2-3$ times.

\section{Conclusion}

Thus, at this stage of works we have shown a possibility of creation of the device of a duplex communication system supporting the USB interface.

At the initial stages of the work connected with development of the program of detection of mistakes and integrity of transmitted data for algorithms which had different values of word length of checksum (8-, 16-, 32 and 64-bits) were obtained.

The test experiments made in city conditions have shown that at high speeds of data transmission (up to $3 \mathrm{~dB}$ ) application of noise immunity coding is most effective. At the same time at reduction of speed of data transmission the efficiency of noise immunity coding decreases. 


\title{
References
}

1 Дмитриев А.В. Динамический хаос. Новые носители информации для систем связи / А.В. Дмитриев, А.И. Панас. М.: Физматлит, 2005. - 252 с.

2 Романов И.В. Нелинейное подмешивание радио- и видеосигналов в системе связи с использованием динамического хаоса / И.В. Романов, И.В. Измайлов, А.П. Коханенко, Б.Н. Пойзнер // Известия Томского политехн. ун-та. — 2011. T. 318, № 2. - C. 53-58.

3 Скляр Б. Цифровая связь. Теоретические основы и практическое применение / Б. Скляр. - М.: Издат. дом «Вильямс», 2003. - 1104 с.

4 Феер К. Беспроводная цифровая связь. Методы модуляции и расширения спектра / К. Феер; под ред. В.И. Журавлева; пер. с англ. - М.: Радио и связь, 2000. - 178 с.

5 Анненков А.М. Модель радиоканала с частотной модуляцией и непрерывной фазой / А.М. Анненков // Журнал радиоэлектроники. — 2011. — № 7. - С. 17.

6 Питерсон У. Коды, исправляющие ошибки / У. Питерсон, Э. Уэлдон. - М.: Мир, 1976. — 596 с.

7 Hinchy S., Khan K. Reed-Solomon Forward Error Correction and the ADF7023. - 2014. — URL: analog.com/ static/imported-files/application_notes/AN-1292.pdf.

\author{
К.М. Маханов, К.Т. Ермағанбетов, Л.В. Чиркова, А.О. Касимов, \\ М.А. Маукебаева, Е.Т. Аринова, К.М. Турдыбекова
}

\section{Шуларға төзімді жылжымалы радио-модемнің прототипі}

Деректермен алмасу үшін USB интерфейсін қолданатын ықшам радиотаратқыш құрылғының дамуының нәтижелері келтірілген. Радиотаратқыш - жиілікпен басқарылатын дабылдармен жұмыс істейтін дуплексті құрылғы. Деректерді беру қателерін түзету Рид-Соломон кодын қолдану арқылы жүзеге асырылды. Алынған деректердің тұтастығы жіберілген деректер пакетін алған соманы салыстыру арқылы бақыланды. Тікелей көріну тұрғысынан әртүрлі деректер жылдамдықтарында максималды тұрақты радиоқабылдағышты эксперименттік зерттеу нәтижелері келтірілген. Эксперименттің мәні алынған деректерді үнемі қадағалап отыру, ал біртіндеп таратушы радиоқұрылғыдан қашықтығын арттыру болды. Күшті кодтауды пайдалану деректердің жоғары жылдамдығымен (3 дБ дейін) тиімдірек болады. Радиобайланыс ауқымын ұлғайту тарату жылдамдығын азайту арқылы мүмкін екенін көрсетті - бұл қабылдағыштың сезімталдығы манипуляция жылдамдығына байланысты. Айта кету керек, құрылғының өлшемдерін құрылымдық өзгерістермен өзгерту мүмкін.

Кілт сөздер: шудың иммунитеті, радиобайланыс, таратқыш, кодтау, деректерді беру, қабылдағыш, өткізу жылдамдығы, микроконтроллер.

\section{К.М. Маханов, К.Т. Ермаганбетов, Л.В. Чиркова, А.О. Касимов, М.А. Маукебаева, Е.Т. Аринова, К.М. Турдыбекова}

\section{Помехоустойчивая мобильная радиосвязь}

В работе представлены результаты разработки компактного радиопередающего устройства, поддерживающего USB интерфейс, для обмена данными. Радиопередатчиком является дуплексное устройство, работающее с частотно-манипулированными сигналами. Коррекция ошибок передачи данных осуществлялась посредством применения кода Рида-Соломона. Целостность принятых данных контролировалась путем сравнения результирующей суммы передаваемого пакета данных с принимаемой. Представлены результаты экспериментальных исследований максимальной устойчивой дальности радиосвязи на различных скоростях передачи данных в условиях прямой видимости. Суть эксперимента заключалась в непрерывном мониторинге принимаемых данных, при постепенном увеличении расстояния от передающего радиоустройства. Применение помехоустойчивого кодирования наиболее эффективно при высоких скоростях передачи данных (до 3 дБ). Показано, что увеличение дальности радиосвязи возможно путем снижения скорости передачи - это обусловлено зависимостью чувствительности приемника от скорости манипуляции. Следует отметить, что уменьшение габаритов устройства возможно путем конструктивной модификации.

Ключевые слова: помехоустойчивость, радиосвязь, передатчик, кодирование, передача данных, приемник, скорость передачи, микроконтроллер. 


\section{References}

1 Dmitriev, A.V. (2005). Dinamicheskii khaos. Novye nositeli informatsii dlia system sviazi [Dynamic chaos. New data carriers for communication systems]. Moscow: Fizmatlit [in Russian].

2 Romanov, I.V., Izmaylov, I.V., Kokhanenko, A.P., \& Poyzner, B.N. (2011). Nelineinoe podmeshivanie radio- i videosihnalov v sisteme sviazi s ispolzovaniem dinamicheskoho chaosa [Nonlinear admixture of radio and video signals in a communication system with use of dynamic chaos]. Izvestiia Tomskoho politekhnicheskoho universiteta - News of the Tomsk Polytechnic University, 318, 2, 53-58 [in Russian].

3 Sklyar, B.(2003). Tsifrovaia sviaz. Teoreticheskie osnovy i prakticheskoe primenenie [Digital communication. Theoretical bases and practical application]. Moscow: Publishing house «Williams» [in Russian].

4 Feer, K. (2000). Besprovodnaia tsifrovaia sviaz. Metody moduliatsii i rasshireniia spektra [Wireless digital communication. Methods of modulation and expansion of a range] (Ed. V.I. Zhuravlev). Moscow: Radio i sviaz [in Russian].

5 Annenkov, A.M. (2011). Model radiokanala s chastotnoi moduliatsiei i nepreryvnoi fazoi [Radio channel model with frequency modulation and a continuous phase]. Zhurnal radioelektroniki - Magazine of radio electronics, 7, 17.

6 Piterson, U., \& Weldon, E. (1976). Kody, ispravliaiushchie oshibki [The codes correcting errors]. Moscow: Mir [in Russian].

7 Hinchy, S., \& Khan, K. (2014). Reed-Solomon Forward Error Correction and the ADF7023, Retrieved from: analog.com/ static/ imported-files/application_notes/AN-1292.pdf. 